\title{
Separatisme, terrorisme, banditisme
}

Anna Libak

En række nyere bøger slår fast, at Ruslands krig i Tjetjenien føres så brutalt, at de russiske styrker snarere bidrager til at skærpe konflikten end til at løse den. Til gengæld hersker der blandt forfatterne en vis uenighed, om Rusland har nogen gavn af krigen

Vibeke Sperling: Åh Tjetjenien Den uendelige krig i Europa.

Gyldendal, 2004, 198 s.

Dmitri V. Trenin and Aleksei V. Malashenko with Anatol Lieven:

Russia's Restless Frontier - The Chechnya Factor in Post-Soviet Russia. Carnegie Endowment for International Peace, 2004. 264 s.

Anna Politkovskaja: Putins Rusland - når magt korrumperer.

Høst E⿱ Søn, 2004, 384 s.

Da det russiske meningsmålingsinstitut Levada Center i august offentliggjorde en undersøgelse af, hvad der optager russerne, var krigen i Tjetjenien end ikke nævnt blandt de ti vigtigste emner. Bekymringen over voksende inflation og arbejdsløshed overskyggede ganske krigen, som russerne ifølge meningsmålingsinstituttets direktør Jurij Levada er kommet til at betragte ligesom "dårligt vejr": Trist, men uomgængeligt.

Efter læsning af den sidste bogsæsons gode bøger om krigen i Tjetjenien kan man roligt konkludere, at befolkningens interesse for krigen overhovedet ikke står i forhold til den betydning for Rusland, som krigen har. Vibeke Sperling begynder sin bog Åh, Tjetjenien, på nøjagtig samme vis som Dmitrij Trenin og Aleksej Malasjenko begynder deres, Russia's Restless Frontier: Nemlig med at citere en prominent politiker for, at "Vi har Tjetjenien over det hele". Og journalisten Anna Politkovskaja 
kunne for så vidt have begyndt sin bog Putins Rusland på samme vis.

For forfatterne er enige om, at den lille nordkaukasiske republik Tjetjenien år for år er kommet til at fylde så vældig meget mere end dens geografiske størrelse på lidt mere end halvdelen af Jylland berettiger til.

Den krig, som Boris Jeltsin i 19941996 efter eget udsagn førte mod en bande separatister i en enkelt af Ruslands 89 republikker og regioner, har Putin siden 1999 gjort til en krig mod hele den internationale terrorisme, der nu kan ramme hvor som helst i Rusland.

Gradvist, men sikkert er konflikten vokset fra i starten af halvfemserne at være en regional konflikt til at blive en del af den russiske stats raison d'etre: På samme måde som staten Israel i høj grad er defineret ved sit forhold til palæstinenserne, er Rusland i dag defineret af sit forhold til Tjetjenien. Alle politiske diskussioner om landets fremtid tager pludselig farve af Tjetjenien, som de i Israel tager farve af Gaza og Vestbredden. Det virker for eksempel underligt sekundært at diskutere sundhedspolitik eller retsreformer i et land ramt af borgerkrig.

Givetvis har man tidligere - før Sharons tilbagetrækning fra Gaza aktualiserede spørgsmålet - også i Israel kunnet lave stribevis af meningsmålinger, hvor forholdet til palæstinenserne overhovedet ikke fremstod som en hovedbekymring.
Det blev opfattet som en præmis for statens eksistens ligesom krigen i Tjetjenien.

\section{Brutal fremfærd}

Forfatterne til de tre bøger er også alle enige om, at en stor del af skylden for eskaleringen af konflikten ligger på russisk side. De føderale styrker har hærget, plyndret, voldtaget og myrdet løs i Tjetjenien, og dermed gjort alt for at overbevise den tjetjenske civilbefolkning om, at den intet godt kan vente sig af en tilværelse inden for den russiske føderation.

Forfatterne bringer flere eksempler, men hvorfor ikke tage et dugfrisk et, da der jo er nok at vælge imellem: I skrivende stund kan man i russisk presse læse, at det stadig er uvist, hvad der er blevet af 11 tilfældige beboere fra den tjetjenske landsby Borozdinovskaja, der pist forsvandt for et par måneder siden efter en natlig "rensningsoperation". Vistnok blev den foretaget af en spetsnaz-enhed fra Vostok bataljonen i den russiske hærs 42. division hvori der indgår mange tjetjenere.

Den militære anklagemyndighed i Nordkaukasus har hårdt presset af mange vidneudsagn åbnet en efterforskning, hvor det militære personel står som hovedmistænkt. Men ingen regner med, at der kommer noget som helst ud af sagen. Der er forsvundet tusinder af tilfældige civi- 
le tjetjenere efter "rensningsoperationer", zatjistki, siden krigens start i 1999, og en tommelfingerregel lyder, at hvis man ikke har hørt fra dem fire dage efter deres forsvinden, så hører man aldrig fra dem igen. I de massegrave, der fra tid til anden dukker op, er ligene nemlig så forkullede, at det som regel er umuligt at fastslå identiteten.

Det er eksempler som disse, der får forfatterne til at konkludere, at de tjetjenske guerillaer frem for alt kan takke de føderale styrker for, at rekrutteringsgrundlaget er så stort i Tjetjenien. Men som Anna Politkovskajas gribende beretninger om forfærdende forhold i den russiske hær indirekte lader forstå, så bliver det sin sag at gøre op med styrkernes brutale fremfærd.

Tag blot historien om menig Jurij Djatjenko, der gjorde tjeneste i omegnen af landsbyen Kalinovskaja i Tjetjenien i 2002. Han blev en aften, hvor han havde vagt, beordret til at hente vodka af 2. års værnepligtige, der snart skulle hjemsendes.

Det er strafbart at forlade sin post under vagttjeneste, og desuden havde han ingen penge, så han nægtede. Så beordrede man ham til at stjæle noget i den tjetjenske by og få vodka på den måde. Han nægtede og blev mishandlet frem til klokken fem næste morgen. De vaskede ham med lort fra latrinen, hamrede en gulvskrubbe op i hans anus, og tvang ham til at spise tre liter risengrød i en køre. Han kunne ikke søge beskyttelse hos officererne, der var i gang med at drikke sig sanseløst berusede ved en fest andetsteds i lejren. Ved sekstiden om morgenen hængte han sig i fødevaredepotet.

Anna Politkovskaja bog er fuld af den slags detaljerede hverdagsberetninger, der efterlader et centralt spørgsmål: Hvis soldaterne behandler deres "egne" sådan, hvordan skal det så være muligt at få dem til at opføre sig ordentligt over for civile tjetjenere, som de anser for potentielle forbrydere? Det bliver altså ikke kun et spørgsmål om at straffe krigsforbrydelser, men om at gøre op med voldskulturen i de føderale styrker.

Som Vibeke Sperling gør opmærksom på, kunne præsident $\mathrm{Pu}$ tin dog til en start lade forstå, at tjetjenere efter hans opfattelse også er en slags mennesker. Om ikke andet så fordi han agter fastholde dem som statsborgere i den russiske føderation. Det kunne Putin såmænd gøre med ganske små virkemidler.

Den 23. februar sidste år var det 60 års dagen for Stalins deportation af tjetjenerne i kreaturvogne til Centralasien som straf for deres påståede - men ikke dokumenterede samarbejde med Hitlers tropper. Sperling fortæller, at der i den anledning blev holdt en mindehøjtidelighed foran den russiske efterretningstjeneste FSB's hovedkvarter Ljubljanka i Moskva. Mindehøjtideligheden blev afbrudt af politiet, der 
arresterede flere af de deltagende menneskerettighedsaktivister, der var kommet for mindes Stalin-tidens ofre. Den 23. februar er nemlig også Hærens dag, og festlighederne i den anledning måtte ikke skæmmes af en tjetjensk demonstration.

Sperling undrer sig med rette over, at Putin ikke benyttede lejligheden til officielt at undskylde eller i det mindste udtrykke medfølelse med tjetjenerne over Stalins folkedrab på dem. Hvad ville det have kostet ham? Intet som helst! Dermed ville han have sendt et signal ikke bare til tjetjenerne, men også til andre indbyggere i Rusland om, at tjetjenere også er mennesker med krav på respekt. Mon ikke det havde bragt en krigsløsning lidt nærmere? Desværre har der ikke været eksempler på, at Putin har opført sig som tjetjenernes præsident.

Ikke engang, da oberst i de føderale styrker Jurij Budanov efter års juridisk tovtrækkeri omsider blev dømt for at have bortført og over flere timer mishandlet en ung fuldkommen uskyldig tjetjensk pige Elsa Kungajeva til døde (der er stærke indicier for, at han også voldtog hende, men det blev han ikke dømt for), benyttede Putin lejligheden til at lægge afstand til Budanov.

\section{Hel eller delvis skyld}

Men selv om forfatterne til de tre bøger er enige om det meste, så er der dog forskelle i analyserne.
Dmitrij Trenin og Aleksej Malasjenko fremhæver, at krigen i Tjetjenien ikke kun har isoleret Rusland fra Vesten, men efter 11. september også har tilnærmet Rusland til Vesten. Groft sagt: De tjetjenske oprørere er blevet Kremls adgangskort til Vestens kamp mod den internationale terrorisme, og uden dem havde Moskva næppe været anset for at have en nøgleposition af såvel USA som Israel, der samarbejder med Rusland om terrorismebekæmpelse.

Ruslands autoritet er altså blevet styrket på grund af krigen i Tjetjenien efter 11. september, hvilket er en smule paradoksalt i lyset af, at samtlige forfattere hævder, at konflikten i Tjetjenien indledningsvis intet havde med international terrorisme at skaffe: For terroren var - i hvert fald oprindeligt - ikke et mål i sig selv for de tjetjenske oprørere, men et middel i kampen for løsrivelse. Terrorangreb mod civile uden fremsættelse af krav er et nyt fænomen, der først er opstået under Putin.

Men krigen har ifølge Trenin og Malasjenko også tjent Ruslands statslige interesser på anden vis. Den har, skriver de, frataget enhver anden af Ruslands i alt 89 regioner og republikker lysten til at blive selvstændige. Tjetjenien er blevet et skrækeksempel på, hvordan det kan gå.

Spørgsmålet er så, om der overhovedet var fare for, at de øvrige republikker ville følge i Tjetjeniens fodspor. Sperling anfører, at de øvri- 
ge republikker allerede havde opgivet tanken om fuld løsrivelse fra Rusland i 1994, da Jeltsin indledte sin krig.

Og dog har Trenin og Malasjenko formodentlig ret $i$, at truslen alligevel lå der latent - den udgik nemlig fra de tjetjenske oprørere selv, som snart begyndte at drømme om at få andre russiske republikker indlemmet i en muslimsk sharia-stat sammen med Tjetjenien. Præsident Putins genoptagelse af krigen mod Tjetjenien var en umiddelbar reaktion på krigsherren Sjamil Basajevs militære felttog mod Dagestan, Tjetjeniens naborepublik mod øst i den russiske føderation. Basajev havde længe drømt om at smelte Tjetjenien og Dagestan sammen til et fundamentalistisk kalifat. I 1998 nedsatte han en folkekongres af tjetjenere og dagestanere og udkastede planer for sammensætningen af de fremtidige ledende organer i fællesrepublikken.

Hans felttog mod Dagestan skete ganske vist $i k k e$ med billigelse fra den siddende tjetjenske præsident, Aslan Maskhadov, der havde kæmpet for at bevare en sekulær stat, og desuden forstod, at angrebet ville føre til krig med Rusland.

Men egentlig var det ligegyldigt for vurderingen af sikkerhedstruslen mod Rusland, om det skete med Maskhadovs accept eller ej. For hvis den tidligere ministerpræsident for et land - Basajev havde været ministerpræsident under Maskhadov - går til angreb på et andet land, uden at landets præsident er i stand til at forhindre det, så har Rusland ret til at forsvare sig.

Ja, man kan hævde, at det for så vidt endda er underordnet, om Basajevs angreb på Dagestan var planlagt i samråd med de russiske efterretningstjenester, som mange øjenvidner til felttoget, hævdede. Hvis så magtfulde kræfter i den tjetjenske republik er villige til at lade sig manipulere til et militært angreb, så er det under alle omstændigheder en sikkerhedstrussel mod Rusland. Desuden var det jo tydeligt, at der ikke var tale om, at en enkelt krigsherre havde fået flyvske fundamentalistiske ideer - store dele af Maskhadovs tidligere entoura$g e$ - Jandarbijev, Barajev, Udugov ønskede en islamisering af Tjetjenien.

I den situation ville $i k k e$ at forsvare sig fra russisk side være det samme som at sætte sig ned og vente på en destabilisering af Tjetjeniens tilst $\varnothing$ dende republikker.

\section{Russisk fejlgreb}

Noget andet er så, at Rusland kunne reagere på truslen på forskellig måde.

Sperling mener tydeligvis ikke, at Basajevs angreb på Dagestan gav Rusland carte blanche til en russisk magtovertagelse, selv om Maskhadov var ude af stand til at tøjle de fundamentalistiske tilbøjeligheder hos 


\section{LITTERATUR Separatisme, terrorisme, banditisme}

sine tidligere kampfæller. Hun skriver, at Vesten "krystalklart" burde have ladet Rusland forstå, at man anerkendte den folkevalgte Maskhadov som Tjetjeniens legitime leder. Og at man derfor ikke ville acceptere indsættelse af en russisk marionetregering på hans plads.

Og givetvis ville det da også have tjent tjetjenernes og folkerettens sag bedre, hvis Rusland havde satset på Aslan Maskhadov og tilbudt ham reel hjælp til at nedkæmpe fundamentalistiske krigsherrer og andre. Så havde der muligvis ikke været krig i dag, for der er ingen tvivl om, at Maskhadov havde befolkningens sympati, mens de fundamentalistiske krigsherrer havde våbnene og pengene. Men det ville have krævet et helt andet og mere fremsynet Rusland.

Tilbage står, at de tjetjenske krigsherrer, som undergravede præsident Aslan Maskhadovs styre og kastede den tjetjenske republik ud i et voldsorgie af kidnapninger og kriminalitet i selvstændighedsperioden fra 1997-1999, er de største forrædere af det tjetjenske folks sag.

Man kan komme med mange gode forklaringer på, hvorfor de blev drevet til at handle som de gjorde; men de gjorde det ikke desto mindre og undergravede dermed det spinkle fundament for tjetjensk selvstyre. Forklaringer fritager ikke for ansvar - hvilket bøgerne også klart gør gældende i tilfældet Putin, der sikkert også har mange gode forklaringer på, hvorfor han handler, som han gør. Det samme kan man sige om de tjetjenere, der i dag har ladet sig indforskrive i Putins "tjetjenisering" af konflikten; en politik, som alle forfatterne forholder sig stærkt kritisk overfor.

Putins strategi er, at republikken skal ledes af lokale, pro-russiske tjetjenere, og det har i praksis kastet republikken ud i en borgerkrig, hvor stridende klaner kæmper mod hinanden med gangstermetoder og med civilbefolkningen som gidsler. Den er under pres fra alle sider: Hvis den samarbejder med det prorussiske tjetjenske styre, risikerer den at blive dræbt af oprørerne. Hvis den samarbejder med oprørerne, risikerer den at blive dræbt af de prorussiske tjetjenere eller af de føderale styrker.

Ja, i det hele taget gør man som tjetjener i dagens Tjetjenien bedst i ikke at blive uvenner med nogen som helst om noget som helst, hvad enten det har med krigen at gøre eller ej - for det flyder med våben, og løse beskyldninger om forræderi kan få fatale konsekvenser. Og på grund af gamle, genoptagne traditioner om blodhævn risikerer tjetjeniseringen at føre til, at Tjetjenien i mange år fremover vil være splittet $\mathrm{i}$ bitre blodfejder.

Igen må man altså konstatere, at dagens tjetjenske magthavere har vist sig at være ligeså ufølsomme over for civile tjetjenere som russerne. Det gør det svært at tro på, at 
Tjetjenien kunne blive en normal, sekulær stat, hvis Rusland trak sig ud. Det ville mindst kræve, at Tjetjenien blev et FN- eller NATO-protektorat med en stor hær af fredsskaben$d e$ styrker. Selv i det tilfælde ville guerillakrigen sikkert ikke afløses af fred: efter så mange års ekstrem krig aner de opvoksende tjetjenske generationer simpelthen ikke, hvordan man lever fredeligt..

"En ituslået kop kan man ikke lime" lyder en russisk talemåde, hvormed menes, at man altid vil kunne se revnerne.

Det er sandt, og dog sidder man efter læsning af de tre bøger tilbage med den følelse, at den tjetjenske civilbefolkning kunne fortjene, at man prøvede alligevel. Det internationale samfunds institutioner - EU, OSCE, Europarådet, FN - kunne starte med at gøre klart, at Rusland ikke burde gøre krav på Tjetjenien, hvis Rusland ikke er i stand til at beskytte og respektere republikkens borgere. Rusland skal have at vide, at dets største nederlag i Tjetjenien til dags dato ikke er af militær, men humanitær og samfundsmæssig art; den tjetjenske befolkning har det efter alt at dømme i dag betydeligt værre end under de facto selvstændigheden i 1997-1999, hvor vold, kriminalitet, kidnapninger og sharialovgivning blev republikkens fundament.
Og i den sammenhæng er det ingen undskyldning, at Rusland blot nedkæmper terrorister med terroristernes egne metoder. Putin må forstå, at en stat er defineret ved sit voldsmonopol, og at det gør, at der er særlige moralske bindinger på en stat. Fordi en tjetjensk bandit skærer hovedet af uskyldige russere, kan de føderale styrker ikke give sig til at skære hovedet af uskyldige tjetjenere.

Den russiske føderation må indse, at den ikke er en føderation af territoriale besiddelser, men en føderation af borgere, og at præsidenten for føderationen følgelig skal har pligt til at beskytte alle borgere uanset etnicitet. Før Putin indser det, sænker freden sig ikke. Og alt tyder på, at han nok skal have international hjælp til den erkendelse.

For som de tre indsigtsfulde bøger, der absolut kan anbefales til læsning, samstemmende dokumenterer, er freden i Tjetjenien i dag langt væk. Siden Sovjetunionens sammenbrud har udsigterne til holdbar fred aldrig været så langt væk som i dag.

Anna Libak er journalist på Weekendavisen 